\title{
The Role of Kiai In Establishing The Accountability of The Nahdlatul Ulama
}

\author{
Novi Wulandari ${ }^{1}$, Ali Djamhuri², Ari Kamayanti ${ }^{3}$ \\ Faculty of Economics and Business, Universitas Brawijaya
}

\begin{abstract}
The purpose of this research is to analyze and describe in depth the reality of the role of Kiai in establishing the Nahdlatul Ulama (NU) accountability. The research perspective used in this study is to use the interpretive paradigm with qualitative research methods and use a collective case studies approach (collective or multiple case study). The use of collective case studies is carried out because in this study not only carried out at the PBNU central office (Pengurus Besar Nahdlatul Ulama), but also at the regional administrator's office, branch administrator's office, muslimat administrator's office, and Islamic boarding school. From the results of the research it was found that besides the role of Kiai, NU also had its own way of accountability. NU's accountability process is called Typical Accountability of Lillahita'ala and Ikhlas in the style of Nahdlatul Ulama.
\end{abstract}

Keywords: Accountability, Kiai, Nahdlatul Ulama (NU)

\section{INTRODUCTION}

Nahdlatul Ulama (NU) is a religious organization born on January 31, 1926 as a representative of traditionalist theologian, with the ideological of ahlus sunnah waljamaah. Figures who play a role are K.H. Hasyim Asy'ari, K.H. Wahab Hasbullah and the theologian at that time. The role of Kiai who fathom Ahlussunnah Wal Jama'ah, can be a place to unite themselves and unite the steps in the task of maintaining, preserving, developing and practicing Islamic teachings by referring to imam madzhab (Hanafi, Maliki, Syafi'i and Hambali) and giving respect to the nation. As NU's development grew, it became one of the largest religious organizations in Indonesia, NU has an unyielding culture that was derived from its predecessors in managing its organization both in the organizational structure and in terms of organizing community-based non-profit organizations with principles of accountability.

$\mathrm{NU}$ is a non-governmental organization (NGO) that organize community-based non-profit organizations that base their organizational management patterns on the principle of mutual cooperation between members and other external parties (eg donors) who share the same concern with the focus of the organization (Attouni and Mustaffa, 2014). Consequently, all organizational decisions and actions must be accountable to all members of the organization and stakeholders in order to create checks and balances that will support the sustainability of the organization. But interestingly, although the process of accountability in non-profit organizations continues to be criticized and doubtful in its reliability (Attouni \& Mustaffa, 2014; Macedo et al., 2016). Many non-profit organizations can continue to work and survive for a long time. Some experts who examine the 
condition of the paradox find the fact that there is a model of accountability that is beyond the mainstream accountability model, such as financial statements and annual reports that are generally used, which are formed from the culture and values adopted by the organization (Awio, Northcott, \& Lawrence, 2011; Berry, 2005; Jacobs, 2005; Jayasinghe \& Soobaroyen, 2009). Thus, although the implementation of organizational accountability is still less effective, especially in terms of the availability of accountability and financial statements, the organization's legitimacy towards all stakeholders is maintained and organizations can continue to do their usual activities (Awio, Northcott and Lawrence, 2011; Berry, 2005; Jacobs, 2005; Jayasinghe \& Soobaroyen, 2009).

Subsquently, another case in the research conducted by Nandya Arnitasari on Accountability of the East Java Provincial Government in Asset Management (2013) was explained that to see how accountability of local government in overcoming land assets that do not yet have certificates can be seen in terms of the program accountability and accountability of the process. In terms of the accountability of the program, the Regional Financial and Asset Management Agency (BPKAD) as the agency that handles the management of regional assets in handling land asset issues that do not yet have a certificate that coordinates with the National Land Affairs Agency (BPN). BPKAD's lack of accountability in overcoming the land certification problem is due to the lack of knowledge of the apparatus in knowing the location and position of the land assets, so it takes a long time in the mapping process, and also lacks coordination with the BPN caused BPKAD negotiations to be weak. Negotiation in accountability process is necessary to control the controlled parties hence the achievement of these targets can be effective and efficient (Nandya, 2013).

Meanwhile, based on the research carried out by Mujayanti (2015), it can be explained that the problems raised in her research about the Majelis Ta'lim Muslimat NU Ukhuwah Islamiyah of Anyar Singaraja Village Bali in managing social aid funds received were apparently in accordance with the proposal submitted. The parties involved in financial management are carried out carefully, openly, honestly and trustfully, where high spiritual understanding is the basis for understanding the accountability of financial management of social aid funds. The concept of financial management accountability in the Majelis Ta'lim Muslimat NU Ukhuwah Islamiyah of Anyar Singaraja Village in Bali includes elements of transparency, liability, control, responsibility, and responsiveness (Mujayanti, 2015).

Furthermore, based on research conducted by Mardiyah on Kiai's Leadership in Maintaining Organizational Culture in Gontor Modern Islamic Boarding School, Lirboyo Kediri, and Tebuireng Jombang Islamic Boarding School (2012), it was explained that the Islamic Boarding School 's cultural at Gontor, Lirboyo, and Tebuireng Islamic Boarding School can be presented with the effectiveness of Kiai's leadership. The leadership is based on the role of the Kiai in maintaining the culture of the Islamic Boarding School through a different selection process, the process of socialization, the actions of top management (Mardiyah, 2012). Based on the research mentioned earlier, 
there are indeed several organizations that have received assistance from both the government and donors, where there are still weaknesses in the process of accountability practices. But there are also non-governmental organization (NGO) such as good religious organizations in their accountability practices.

In the development of accountability practices carried out by the NU organization, there were still some weaknesses in it. There are two main indicators show that the application of accountability practices is still weak in NU, namely: First, the management of the NU organization prioritizes the style and tradition of Islamic Boarding School management. The management of this Islamic Boarding School fully places the Kiai as the main decision maker. This is because historically NU is also an Islamic Boarding School (Baso, 2013, 2015). The Islamic boarding school that Kiai fostered, had great contribute from the beginning of the establishment of NU to the present (Baso, 2013, 2015). Moreover. Kiai tend to be preferred that make all aspects of the organization are dependent on Kiai's decisions (Baso, 2013; 2015). This causes the decision making of NU not to be based on the organizational structure and document data that the organization has. Secondly, NU has not paid attention to the importance of the management system and financial accountability. During this time, NU has only managed its finances based on reports of cash receipts and disbursements. This is closely related to the previous paragraph explanation, which is due to the fact that all aspects of the organization are dependent on the Kiai caused financial information tends to only be known in the form of cash receipts and disbursements.

The weakness of NU's accountability, as one of the non-government organizations (NGO) that focuses on solving social problems by relying on Islamic views, and is non-profit, is not something that has just happened. Based on the paradoxical explanation of the conditions of accountability within the NU, it becomes interesting to examine NU's accountability deeper. In particular, in order to look for the possibility of the presence of a accountability model in NU beyond the mainstream accountability model. Based on the facts, even though NU has not fully implemented the mainstream accountability model, NU's legitimacy among its members has been maintained to become the largest community organization in Indonesia.

The results of observations conducted by researchers at the Jakarta PBNU office, East Java PWNU, Malang City PCNU, Malang Regency PCNU, Muslimat Management, and Tebu Ireng Jombang Islamic Boarding School were found several different cases, namely Jakarta PBNU, Implementation of accountability is one of the programs of the PBNU Chairperson. As one of the respected Kiai in NU, he hopes for, launches, and runs an accountability movement in various elements and autonomous parties of NU. But in fact, the implementation of accountability is still minimal and almost none in NU. Even if there are any, is not comprehensive. In the preliminary interview the Chairperson of the PBNU explained the assets owned by NU, which is the assets have not yet been able to be valued up until now, therefore NU itself cannot incorporate the value of these assets into its financial statements yet. 
At the Regional management level, accountability is almost impossible because of various constraints such as limited human resources, traditional patterns and organizational habits, the impediment of the Kiai on the concept of accountability as a modern concept applied in traditional NU organizations. In the management of the Muslimat Center, accountability exists and is well established. Fund reports and activities equipped with documentation can be easily accessed in both print and electronic forms. The use of information technology in the form of WA (Whatsapp) groups, BB (Blackberry Messenger), and FB (Facebook) is already established and is an intensive medium of communication and information delivery. Seeing the reality that occurs, the theoretical approach used in this study is to use the concept of organizational culture theory with organizational value types. The concept of organizational culture can be understood in three madzhab, namely: First, Madzhab of Ideational School, this madzhab looks more at the culture of an organization from what is shared (understood, imbued and practiced together) by members of a community. Second, the Adaptationist School madzhab, looks at the culture of what can be observed both from the organizational building such as the architecture/spatial structure of an organization's physical building. Third, Realist School Madzhab, which is to see organizational culture is something complex that cannot be understood only from the behavior patterns of its people but also the source of these behaviors.

Organizational culture according to Edy Sutrisno (2010) is meant as a system of values, beliefs, assumptions, or applicable norms, agreed and followed by members of an organization as behavioral guidelines and organizational problems solvers. Because this value is the result of a culture, the value approach used is use the type of values in Wiener's organization. uses the type of value in the organization based on the perspective of organizational members as the basis to which espoused values are considered central and how far these values are shared by members of the organization. Furthermore, (Warrick, 2017) divides this type of value into two dimensions, namely whether the values are functional or elitist. Functional values are organizational values which are as guidelines for organizational members in carrying out activities in the organization. Whereas Elitist Values are organizational values that emphasize the importance of an organization or pride in the organization.

By using the organizational culture approach with this type of value, the hope of the role of Kiai in forming the accountability of the Nahdlatul Ulama (NU) can be known. This is because the organizational culture cannot be separated from the role of the leader, including the role of Kiai in forming NU accountability. This view is in accordance with the opinion of (Warrick, 2017), who said that the formation of organizational culture cannot be separated from the role of its leaders. For this reason, this research seeks to conduct in-depth studies to see the role of Kiai in forming Nahdlatul Ulama Accountability (NU) with the aim of analyzing and deeply understanding the reality of the role of Kiai in establishing the Nahdlatul Ulama (NU) Accountability. 


\section{METHOD}

This research is carried out by using a qualitative research method. This is because in the interpretive perspective, the selection of the qualitative method puts the researcher into a close relationship to the object of research, where the researcher seeks to understand or interpret phenomena in terms of meaning. For this reason, this study seeks to show that accounting not always be explained through the presentation of complicated numbers, but accounting can be explained in a qualitative. Then the type of research used is using a type of case study approach, where case studies are qualitative research approaches that are used to understand an issue or problem using a case (Creswell, 2007)

In this research, the type of case study used by researchers is using collective or multiple case studies. Because the cases studied focus on only one issue or focus, but to illustrate the issue, limited cases are used. This research not only was carried out at the Central PBNU office (the Executive Board of the Nahdlatul Ulama), but also in the regional administrator's office, branch administrator's office, Muslimat administrator's office, and Islamic boarding schools.

Then the data analysis used in this study use qualitative data analysis, the interactive model of analysis model. Qualitative data analysis (Moleong 2007) is an effort carried out by working with data, sorting it into manageable units, discovering what is important and what is learned, and deciding what can be told to other people. Then the analysis of the interactive model itself consists of three components, namely (Miles, at al, 2014) (1) Data Condensity, collected data from the observation process in the field is noted in a detailed report. Data condensity is carried out continuously during the research process; (2) Data Display, this is intended to make it easier for researchers to be able to see the overall picture of certain parts of the research data; (3) Concluding Drawing, in this case the data verification is carried out continuously throughout the research process. Stages to draw conclusions from categories of data that have been reduced and then presented to final conclusions that are able to answer the problems.

Besides that, this research also used method in data collection, method of data collection techniques is a part of the data collection instrument that determines the success or failure of a research. Data collection is a technique or ways that can be used by researchers to collect data. In this study data collection techniques are used observation, data collection is carried out by researchers by making direct observations in the field of the object under research. The next technique is in-depth interview, this interview is a process of obtaining information for the purpose of research by face-to-face question and answer between interviewers and respondents or interviewees, using or without interview guidelines (Moleong, 2007). The reason the researchers used in-depth interviews was because the advantages of this method lay in the purity of the data obtained from an informant and not influenced by outside parties. Then the last technique used is documentation, this method is done through recording or copying data in the research location. Usually 
this data is in the form of secondary data or existing data, such as archives, photographs, annual reports, meeting results, or other documents in the field relating to this research.

\section{RESULTS \& DISCUSSION Result}

Nahdlatul Ulama as a large organization, has an unyielding culture that has been derived from its predecessors. From the history of NU's establishment and research, the researchers found that NU must be understood from the NU's own side. NU must be understood from the context of the archipelago culture which is very thick with traditions and norms found in Islamic boarding school. In general, in the process of accountability, starting from the central level to the branch, it has not been found neat entry, structured, and published continuously to the public as a form of organizational responsibility to the public. This certainly explains that the achievements that have occurred sporadically and are dependent on the ability of a group of administrators, rather than as an embodiment of NU's vision and mission or an achievement that can be recognized as NU's overall success.

On the other hand, Gus Mujib Syadzili as Deputy Chair of Tanfidziah PCNU Malang Regency have another view that good administration does not always produce interest from pilgrims as well. This is evidenced in terms of membership which up to the level below is still maintained in NU, even though it is managed traditionally. For this reason, if the Nahdlatul Ulama (NU) is arranged in a modern way, it will have an impact on the number of pilgrims who are getting smaller. Basically, accountability is a modern concept that emphasizes the cultural values of transparency in organization. But in fact, NU already has a different style from modern accountability theories. The Nahdliyin trusted the Kiai as their predecessors had influence on their students before being in the form of NU nowadays. This is due to the fact that most of the NU administrators were students who were truly obedient to Kiai. According to Gus Mus Kiai, he has the same thoughts and behaviours as other Kiai to imitate the footsteps of the Prophet Muhammad wherever possible. This is what makes the students who run as administrators of the NU organization believe that the Kiai is the successor of the Prophet who must be obeyed and imitated.

The opinion conveyed by Gus Mus was then the main point of NU people's trust in NU itself. The establishment that the Kiai are the successors of the Prophet Muhammad is a guarantee that is more credible than a set of accountability parameters initiated by the modern world. The basic composition of the NU community is mostly Ahlussunah Wal Jamaah. Gus Mus's opinion is also in line with Vijay Sathe (1985) as a monolithic culture in which Nahdlatul Ulama (NU) shares assumptions or shares the same values with all members of the organization such as for Bansers, or there are terms that arises Wallohul Muwafiq ila aqwamith Thariq in religious activities.

Meanwhile, the Nahdliyin people who want to gain access to NU's financial statements, according to Gus Mujib Syadzili, can be seen from the 
end of each change of position at the plenary meeting delivered in the annual report. Although the report is only limited to cash receipts and disbursements, it is still accepted with trust that all NU members run the organization sincerely, lillahita'ala, and do not do anything negative.

This opinion shows that NU is an organization consisting of pilgrims whose majority are still had traditional mindset. This mindset is based on their efforts as a manifestation of their love for NU. The preparation of financial statements that have been conducted is still limited to cash receipts and disbursements. Gus Solah stated that reporting to the public was almost nonexistent. Based on interviews researchers with Tin Farida Yahya, as Chair of the NU Branch in Malang Regenc that on the principle of honesty and sincerity, the financial statements are mostly minus, but the activities are still continuously and completed. In other words, the financial condition of the cash is indeed minus, but because of this sincerity, even though it is not recorded, all activities are done well as a result of the sincerity and honesty of Nahdliyin. Although sometimes the Kiai must give their personal funds in addition, but the sincere donors do not stop and continue to contribute their sincerity.

\section{Discussion}

From the observation of the case conducted by researchers, the researchers found that the accountability of Lillahita'ala and Ikhlas was based on the presence of NU programs or activities. If the religious activities are present in the midst of $\mathrm{NU}$, so the $\mathrm{NU}$ residents themselves have felt that the $\mathrm{NU}$ management's responsibilities in NU are seen as Lillahi Ta'ala's actions, actions to support the organization in hopes of gaining blessings from Allah SWT. Looking at the role of Kiai in forming the accountability of Nahdlatul Ulama in the concept of organizational culture with value types, this research can be assessed using the Wiener value type approach. According to Weiner (1989) there are two dimensions of value, namely the focus of these values which are divided into two categories, namely whether these values are functional or elitist. Therefore, in looking at the reality of the role of Kiai in forming NU accountability, it will be seen whether the role of the Kiai falls into the following categories of value types (1) Elitist-charismatic values type is a value system that is feared not to contribute to long-term success for the organization because it comes from leaders organizations that are transitional or also interpret the system of pride values from charismatic leaders which results fanaticism among members of the organization; (2) Functional-charismatic values type is representations of functional types that are believed to contribute to the effectiveness of the organization with traditional organizational values; (3) Functional-traditional values type, namely organizational values that are functional and derived from the previous generation. The typical of this organization value is believed to be able to contribute the effectiveness of organizational performance because: a) Quite broad participation among members of the organization and b) Values are difficult to adapt by other organizations looking by the gradual 
formation process; (4) Elitist-traditional values type is organizational values that last from one generation to the next (Weiner, 1989).

Based on the discovery in this research, it is known that NU has its own way of accountability. NU's accountability process is called Typical Accountability of Lillahita'ala and Ikhlas in the style of Nahdlatul Ulama. The aim of the Lillahita'ala and Ikhlas accountability is the principle of honesty and sincerity in preparing financial statements. Even though financial condition of the cash is indeed minus, but because of this sincerity, even though it is not recorded, all activities are done well as a result of the sincerity and honesty of Nahdliyin. Although sometimes the Kiai must give their personal funds in addition of sincerely donors. The principle of honesty and sincerity in preparing financial statements or as the Typical Accountability of Lillahita'ala and Ikhlas style of the Nahdlatul Ulama run by the NU administrators certainly reflects the Functional-values type, because the values of the NU organization with the Typical Accountability of Lillahita'ala and Ikhlas style of the Nahdlatul Ulama is organizational values that serve as a guideline for members in preparing financial statements that are functional and come from previous generations and are proven to last from one generation to the next. The Typical Accountability of Lillahita'ala and Ikhlas style of the Nahdlatul Ulama that lasts from one generation to the next, then the organizational values are then transformed into a functionaltraditional values type. This is based on the representation of functional types by contributing to the effectiveness of the performance of NU's financial statements with the principles of honesty and sincerity. The values of honesty and sincerity in preparing financial statements that are limited to cash receipts and disbursements can make considerable participation among members of the $\mathrm{NU}$ organization itself, therefore it becomes difficult to be adapted by other organizations, given by the gradual formation process and also does not follow the concept of modern accountability thinking.

Whereas the role of the Kiai who has a great influence on the students certainly makes Kiai obeyed by the NU organization's administrators. This is because the NU administrator is a student, according to Gus Mus Kiai, he has the same thoughts and behaviours as other Kiai to imitate the footsteps of the Prophet Muhammad. This condition makes the students who run as administrators of the NU organization believe that the Kiai is the successor of the Prophet who must be obeyed and imitated. By referring to this, NU's administrators has become a guarantee that is more reliable than a set of parameters in everything, not least in arranging accountability as was initiated by the modern world.

Such a large role of Kiai is categorized in the value of the Elitistcharismatic values type, which is a pride values system on charismatic leaders which results fanaticism among members of the organization. Given the charismatic of the kiai is temporary that make these values are transitional. When the values in the NU organization originating from the founders of the Islamic boarding school can survive until now, then this type of value changes to the Elitist-traditional values, because the underlying values of the operations carried out by the NU organization are adopted from 
the Islamic boarding school and are elite and stable and enduring from one generation to the next. Thus demonstrating the values of the NU organization can contribute to the success of an organization that is able to survive in the long term.

The success can also be seen from the process of accountability, which is still at financial statements, cash receipts and disbursements. However in fact, NU organizations are still developing and even becoming the largest organization in Indonesia until now even though the process of accountability from the central level up to the branch has not yet found structured and continuously published to the public as a form of organizational responsibility to the public.

\section{CONCLUSION}

Based on research on the role of Kiai in forming the Nahdlatul Ulama Accountability (NU), it is known that besides the role of Kiai, NU also has its own way of accountability. NU's accountability process is called "Typical Accountability of Lillahita'ala and Ikhlas in the style of Nahdlatul Ulama". The aim of of Lillahita'ala and Ikhlas accountability is the principle of honesty and sincerity in preparing financial statements. The existence of Kiai role in the concept of value types according to Weiner is categorized as having the value of the Elitist-charismatic values type, which is a value system of pride from charismatic leaders that results in fanaticism among members of the organization. Because the charismatic nature of the Kiai is temporary, these values are transitional. Given that the values in the NU organization originating from the founders of the Islamic boarding school are able to run up to now, then this type of value changes to the Elitist-traditional values type, because the underlying values of the operations carried out by the NU organization that adopted from the Islamic boarding school are elite and stable from one generation to the next. Thus demonstrating the values of the NU organization can contribute to the success of an organization that is able to survive in the long term. Then based on the results in this research, the process of Lillahita'ala and Ikhas NU's accountability which is principled with honesty and sincerity can continue and run because even though financial condition of the cash is indeed minus, but because of this sincerity, even though it is not recorded, all activities are done well as a result of the sincerity and honesty of Nahdliyin. The principle of honesty and sincerity in preparing financial statements or as the Typical Accountability of Lillahita'ala and Ikhlas style of the Nahdlatul Ulama run by the NU administrators certainly reflects the Functional-values type, because the values of the NU organization with the Typical Accountability of Lillahita'ala and Ikhlas style of the Nahdlatul Ulama is organizational values that serve as a guideline for members in preparing financial statements that are functional and come from previous generations and are proven to last from one generation to the next. The Typical Accountability of Lillahita'ala and Ikhlas style of the Nahdlatul Ulama that lasts from one generation to the next, then the organizational values are then transformed into a functional-traditional values type. This is based on the representation of functional types by 
contributing to the effectiveness of the performance of NU's financial statements with the principles of honesty and sincerity. The values of honesty and sincerity in preparing financial statements that are limited to cash receipts and disbursements can make considerable participation among members of the NU organization itself, therefore it becomes difficult to be adapted by other organizations, given by the gradual formation process and also does not follow the concept of modern accountability thinking. Even though NU's accountability process is still simple, in fact $\mathrm{NU}$ is still developing and has even become the largest religious organization in Indonesia until now.

\section{REFERENCES}

Attouni, M.A.K., Mustaffa, C.S. 2014. How do Non-profit Organizations in Libya Adopt and Use Social Media to Communicate with The Society. Procedia - Social and Behavioral Sciences, The International Conference on Communication and Media 2014 (i-COME'14) Communication, Empowerment and Governance: The 21st Century Enigma 155, 92-97. https://doi.org/10.1016/j.sbspro.2014.10.262

Awio, G., Northcott, D \& Lawrence, S. 2011. Social Capital and Accountability in Grass Roots NGOs: The Case of The Ugandan Community-Led HIV/AIDS Initiative. Accounting, Auditing \& Accountability Journal, 24(1), 63-92. http://doi.org/10.1108/09513571111098063

Berry, A. J. 2005. Accountability and Control in a Cat's Cradle. Accounting Auditing \& Accountability Journal, 18(2), 255-297, http://doi.org/10.1108/09513570510588781

Creswell, J. . 2007. Qualitative Inquiry \& Research Design: Choosing Among Five Approaches, 2nd ed. California: Sage Publication.

Jacobs, K. 2005. The Sacred and The Secular: Examining The Role of Accounting in The Regilious Context. Accounting, Auditing \& Accountability Journal, 18(2), 189-210, http://doi.org/10.1108/09513570510588724.

Jayasinghe, K., \& Soobaroyen T. 2009. Religious "spirit" and peoples perceptions of accountability in Hindu and Buddhist religious organizations. Acounting, Auditing \& Accountability Journal, 22(7), 997-1028. http://doi.org/10.1108/095

Macedo, I.M., Pinho, J.C., Silva, A.M., 2016. Revisiting the link between mission statements and organizational performance in the non-profit sector: The mediating effect of organizational commitment. European Management Journal 34, 36-46. https://doi.org/10.1016/j.emj.2015.10.003

Kovach, H., Neligan, C., \& Burali, S. 2003. Power Without Accountability The Global Accountability Report 1, One World Trust, London, pdf download available at: www.oneworldtrust.org/htmlGAP/report Mardiyah. 2012. Kepemimpinan Kiai dalam Memelihara Budaya Organisasi di Pondok Modern Gontor, Lirboyo Kediri, dan Pesantren Tebuireng Jombang. Jurnal TSAQAFAH, 8 (1). 
Mujayanti, M. 2015. Akuntabilitas Pengelolaan Keuangan Dana Bansos Pada Majelis Ta'lim Muslimat Nu Ukhuwah Islamiyah Kampung Anyar, Singaraja, Bali. e-Journal S1 Ak. Universitas Pendidikan Ganesha Jurusan Akuntansi Program S1, 3 (1).

Miles, M.B., Huberman, A.M., \& Saldana, J. 2014. Qualitative Data Analysis: A Methods Sourcebook. Sage, London.

Moleong, L.J. 2007. Metodologi Penelitian Kualitatif. Bandung: PT. Remaja Rosdakarya Offset

Nandya, A. 2013. Akuntabilitas Pemerintah Provinsi Jawa Timur dalam Pengelolaan Aset. Jurnal Kebijakan dan Manajemen Publik, 1(1).

Roughton, J., Crutchfield, N., Waite, M.. 2019. Chapter 2 - Analyzing the Organizational Culture, in: Roughton, J., Crutchfield, N., Waite, M. (Eds.), Safety Culture (Second Edition). Butterworth-Heinemann, pp. 35-52. https://doi.org/10.1016/B978-0-12-814663-7.00002-9

Warrick, D.D. 2017. What leaders need to know about organizational culture. Business Horizons 60 , 395-404. https://doi.org/10.1016/j.bushor.2017.01.011 